\title{
Pedunculate Oak Leaf Miners' Community: Urban vs. Rural Habitat
}

\author{
Jovan Dobrosavljević ${ }^{1, * \mathbb{C}}$, Čedomir Marković ${ }^{1}$, Marija Marjanović ${ }^{2}$ \\ and Slobodan Milanović 1,3 \\ 1 Department of Forest Protection, Faculty of Forestry, University of Belgrade, Kneza Višeslava 1, \\ 11030 Belgrade, Serbia; cedomir.markovic@sfb.bg.ac.rs (Č.M.); slobodan.milanovic@sfb.bg.ac.rs (S.M.) \\ 2 Department of Landscape Horticulture, Faculty of Forestry, University of Belgrade, Kneza Višeslava 1, \\ 11030 Belgrade, Serbia; marija.marjanovic090@gmail.com \\ 3 Department of Forest Protection and Wildlife Management, Faculty of Forestry and Wood Technology, \\ Mendel University in Brno, Zemedelska 3, 61300 Brno, Czech Republic \\ * Correspondence: jovan.dobrosavljevic@sfb.bg.ac.rs; Tel.: +381-603-375707
}

Received: 6 November 2020; Accepted: 30 November 2020; Published: 3 December 2020

\begin{abstract}
With the process of urbanization, cities are expanding, while forests are declining. Many conditions in the urban habitats are modified compared to those in the rural ones, so the organisms present reactions to these changes. To determine to what extent the habitat type influences insects, we tested the differences in the pedunculate oak (Quercus robur L.) leaf-mining insect community between urban and rural habitats in Serbia. Lower species richness, abundance, and diversity were determined on trees in the urban environment. Due to the differences in the habitat types, many of the species disappeared, while most of the remaining species declined. The seasonal dynamics of species richness, abundance, and diversity differed between the habitat types. Both rural and urban populations started with low values in May. Subsequently, rural populations gained higher species richness, abundance, and diversity. As about $60 \%$ of the leaf miners' species present in the rural habitats survive on the trees in urban areas, those trees are of great importance as a species reservoir. This is why we need to preserve and strive to improve the condition of urban areas where the pedunculate oak is present.
\end{abstract}

Keywords: abundance; diversity; seasonal dynamics; Serbia; species richness

\section{Introduction}

Forests are among the most species-rich habitats on the planet [1,2]. Their area is rapidly declining due to the growth of the human population, expansion of urban areas, as well as the increased need of humankind for food and natural resources [3-7]. However, woody vegetation is also present in those urban areas in the form of tree rows, parks, gardens, shelterbelts along roads, and railways, etc. [8]. The environment in the urban areas differs from that in nature in terms of climatic and edaphic conditions, surface area and connectivity of habitats, composition and structure of vegetation, pollution, and intensive human activity [9-15]. Fragmentation and air pollution, as well as an increase in temperature and $\mathrm{CO}_{2}$ concentration influence the present insect fauna by loss of habitat and food quality $[9,11,16-18]$. The insects react by physiological and behavioral alterations, changes in body size, spatial distribution, and reproduction and survival rates [19]. These changes can consequentially influence their diversity and seasonal dynamics [9,16,20-24]. Some species of generalist insects survive in urban areas, and these altered conditions suit them even better $[11,18,25,26]$. On the other hand, many species of specialist insects are negatively affected $[11,18,24,27,28]$, as they are trophically connected with specific hosts [29-31]. Most herbivorous insects belong to the group of specialist 
insects [32]. Herbivorous insects comprise about half of all described insect species [33] and are both consumers and prey for other species higher in the trophic chain [16,31,34]. Consequently, they play an important role in all terrestrial ecosystems in which plants are present. Changes in all of the herbivorous insect species are difficult to analyze, so some groups or individual species are used as indicators of alterations in the environment $[35,36]$. Leaf miners are suitable for monitoring those environmental changes as they are closely connected with their host plant, so they react to the changes to which the host plant is exposed [35,37]. Leaf miners are well studied in Serbia, and the presence of over 370 species is determined [38-42]. Of those species, only 28 were identified on Q. robur [41].

Not many studies have been conducted on the differences in endophagous herbivorous insects between urban and rural habitats [16,43]. Most of them agree that consequences of urbanization such as elevated temperature and $\mathrm{CO} 2$ concentration, and changes at the landscape level are the most important factors influencing those insect communities $[9,16,28,44]$. In addition to these, indirect effects such as changes in plant traits, predator and parasitoid assemblages, and their attack rates also play an important role $[9,16,28,44]$. Not all endophagous herbivorous insect species respond to these effects in the same manner $[35,43]$. Studies that dealt with the influence of changes caused by urbanization on leaf miners found contrasting results $[9,16,28,44-46]$. The majority of those studies examined only individual species $[9,28,44,45]$. They concluded that some species were positively influenced by the habitat alterations caused by urbanization [28,44,45]. On the other hand, Rickman and Connor [9] found the influence to be positive on some and negative on other species. The studies that dealt with the effect of habitat type on the leaf miner community reported no significant differences between their species richness and abundance in the urban and rural environments $[9,16]$.

The differences between urban and rural habitats can also influence the herbivorous insects' seasonal dynamics. Higher temperatures and $\mathrm{CO}_{2}$ concentrations in the urban areas $[16,22,47]$ can affect these insects both directly, by modifying their phenology and development, and indirectly, by modifying the phenology and development of their host plants, predators, and parasitoids [16,20-23]. The increase in temperature can affect the insects positively by accelerating their metabolism [21]. This consequentially causes faster development of preimaginal stages which leads to greater survival rates, longer activity throughout the year, and development of more generations per year [21,48]. Indirectly, this increase in temperature causes faster plant growth and allows a longer vegetative period [21]. On the other hand, those plants start developing earlier in the season, so the synchronization between the development of the insects and the host plants can be disturbed and can cause greater mortality rates [21]. No previous studies on the differences in the leaf-mining insects' seasonal dynamics between urban and rural habitat types have been conducted to date. Because habitat type affects the seasonal dynamics of other groups of insects $[48,49]$, we presumed that it would affect the leaf miners as well.

The results of the previous studies on the differences in leaf miners between urban and rural habitats did not coincide, and most of them were conducted on individual species level. Therefore, we decided to investigate how the differences in habitat type influence the pedunculate oak leaf miner community, as well as some of the most frequent individual species. Additionally, there are no previous studies on the differences in the leaf-mining insects' seasonal dynamics between urban and rural habitat types. As a result, we decided to determine how the months of the vegetative season and habitat type influence the leaf miners' community. To do that, we determined the leaf miners' species richness, frequency of occurrence, abundance, and diversity on trees in the urban and rural habitat throughout the vegetative season. The aim of the study was to answer the questions: (1) Do differences exist between the pedunculate oak leaf miner communities in urban and rural habitats? (2) Does the seasonal dynamics of pedunculate oak leaf miners differ between urban and rural habitats? 


\section{Materials and Methods}

\subsection{The Host Plant and the Investigated Insects}

Pedunculate oak (Quercus robur L.) was chosen as a host plant for testing the influence of habitat type because it is widespread in both rural and urban habitats in Europe [43,44]. Natural pedunculate oak forests are declining due to the influence of many biotic and abiotic factors [45,46]. Therefore, trees in the urban environment are becoming increasingly important, as they present a valuable habitat for a great variety of organisms. Among those organisms, insects present one of the most species-rich and diverse groups [50-52]. One guild of oak inhabiting insects-leaf miners-was chosen for testing the influence of the habitat type because they satisfy most of the requirements one group of bioindicators needs to fulfill [53]. They are a diverse insect group, with a large number of species, taxonomically well studied, and distributed worldwide on a large number of hosts $[29,30,54,55]$. Leaf miners are small, and the adults can fly only over short distances, so they cannot migrate far $[9,56,57]$. Their larvae are closely connected with their host plant, and therefore, they react to changes to which it is exposed [35,37]. Leaf miner species are also mostly monophagous and narrowly oligophagous, so individual plant species or genera have a specific complex of leaf miners $[29,30,55]$. Some species belong to insect orders, which are commonly used as bioindicators such as Coleoptera and Lepidoptera $[58,59]$. They are easily collected and analyzed, as they spend their larval stage in one leaf $[9,29]$. Even after development or death, the mine remains on the leaf $[9,29]$.

\subsection{Study Sites}

The research was conducted in 2017 on 4 localities in Serbia, two in rural oak stands (Obrež-44 $45^{\prime} \mathrm{N}, 19^{\circ} 57^{\prime} \mathrm{E}$ and Progar-Bojčinska šuma- $44^{\circ} 44^{\prime} \mathrm{N}, 20^{\circ} 08^{\prime} \mathrm{E}$ ), and two in urban areas (Ada Ciganlija— $44^{\circ} 47^{\prime} \mathrm{N}, 20^{\circ} 24^{\prime}$ E and Košutnjak—44 $45^{\prime} \mathrm{N}, 20^{\circ} 25^{\prime} \mathrm{E}$ ) (Supplementary Figure S1). The average annual temperature in all the investigated localities is $10.9^{\circ} \mathrm{C}$. The average annual rainfall is $682 \mathrm{~mm}$ on all the localities except Obrež, where it is $570 \mathrm{~mm}$. The plants at the two localities in the rural habitats additionally use groundwater that is abundant there, especially during spring. The dominant soil type on three of the localities is eutric cambisol, and it is fluvisol on locality Ada Ciganlija [60,61]. The presence of pedunculate oak trees of similar age and dimensions (about 100 years old, with a height of about $20 \mathrm{~m}$ and a diameter of about $50 \mathrm{~cm}$ ) is constant in all localities.

Dense, mostly pure, pedunculate oak stands are present on localities Obrež and Progar (rural habitat type). They are represented in the form of forest fragments along the Sava river and cover an area of more than 500 ha. No silvicultural operations were conducted in the investigated stands recently or during the sampling period.

Localities Ada Ciganlija and Košutnjak are mostly covered by forest parks (urban habitat type). Pedunculate oak is present in separated groups of four to nine trees, isolated from the pedunculate oak forests. Vegetation on these localities has been anthropogenically altered by cutting of trees and by planting other autochthonous and allochthonous tree species. Many of the lower tree branches have been pruned, and most of the understory shrub vegetation has been removed. The canopy cover in these areas is significantly reduced. There are numerous gaps and openings, so the groups of trees are frequently isolated by open areas such as lawns, sports fields, and playgrounds. These areas are mowed and treated for mosquitos and ticks every year. Human activity here is intensive throughout the whole year. As these parks are very popular, there are many roads and parking lots in their vicinity.

\subsection{Sampling Design}

On each locality, four spatially separated blocks, each containing four pedunculate oak trees of similar dimensions, were randomly selected (16 trees per locality, 32 per habitat type). Once a month, in the period May-October, 50-100 cm long apical parts of four randomly selected leaf baring-branches were cut from the selected trees. The branches were cut up to a height of about $8 \mathrm{~m}$ above the ground. The cut branches were then brought to the Entomological Laboratory of Belgrade University, Faculty of 
Forestry, where the total number of leaves, as well as the number of leaves with mines on them, was determined. The mined leaves were then separated, and species causing them were identified based on Hering, Patočka and Turčani, Laštůvka et al. and Ellis [29,55,62,63].

\subsection{Characteristics of the Leaf Miner Community Analyzed}

The leaf mining insect community was quantified by the following parameters at the level of a single tree:

1. Species richness (number of species identified);

2. The abundance of individual species $\left(A_{i}\right)$ (number of mines per 100 leaves), calculated as:

$$
A_{i}=\frac{n_{i}}{l_{i}} * 100
$$

3. The abundance of leaf miners $\left(A_{b}\right)$ calculated as a sum of all individual species' abundance;

4. Shannon index of diversity $(H)$, calculated as:

$$
H=-\sum_{i=1}^{s}\left(\frac{n_{i}}{N}\right) \ln \left(\frac{n_{i}}{N}\right)
$$

5. Frequency of occurrence $\left(F_{q}\right)$, calculated as:

$$
F_{q}=\frac{u_{i}}{U} * 100
$$

where $n_{i}$ is the number of mines of one particular species found in one sample, $l_{i}$ is the number of leaves per sample, $N$ is the total number of mines found, $u_{i}$ is the total number of samples in which a particular species was found, and $U$ is the total number of samples. The diversity indices were determined using PAST Version 3.18 software (Øyvind Hammer, Natural History Museum, University of Oslo).

\subsection{Statistical Analysis}

As the distribution of the analyzed parameters did not fit any of the standardized distributions (Kolmogorov-Smirnov test), nonparametric tests were used for further analysis. The Mann-Whitney $\mathrm{U}$ test was used to determine the influence of habitat type on both the total and the species richness, abundance, and diversity in individual months (month as a grouping variable). The Mann-Whitney $\mathrm{U}$ test was also used for testing the influence of the habitat type on the total abundance of frequent (present in $>20 \%$ of samples) leaf miner species. Friedman ANOVA was used to determine the influence of the month of the vegetative season on abundance and diversity separately in urban and rural habitats. All the data were analyzed at the tree level, at the level of significance 0.05 . All of the statistical analyses were performed using Statistica 8.0 (StatSoft, Inc., Tulsa, OK, USA).

\section{Results}

\subsection{Overall Species Richness, Frequency of Occurrence, and Abundance of Leaf Miners}

The collected samples contained 90,842 leaves with 10,566 mines on them. Of those mines, 7746 were identified at the species level. These mines were caused by 30 species of leaf miners (Table 1). On average, there were $3.92 \pm 2.87$ species of leaf miners per tree. The most frequent species were Phyllonorycter harrisella (Linnaeus, 1761) and Caloptilia alchimiella (Scopoli, 1763), which were recorded in more than $90 \%$ of the samples. In addition to these, 10 other species were also frequent (present in more than $20 \%$ of samples) (Table 1). The abundance of most species (13) ranged between 0.01 and 0.1 mines per 100 leaves. The five species that had an abundance greater than one mine per 100 leaves, caused around $85 \%$ of the total number of mines identified at the species 
level (Tischeria ekebladella (Bjerkander, 1795)—24.55\%, Ph. harrisella-20.35\%, C. alchimiella-14.53\%, Phyllonorycter roboris (Zeller, 1839)—13.85\%, Ectoedemia caradjai (Groschke, 1944)-11.68\%). The leaf miners made $10.16 \pm 11.77$ mines per 100 leaves on average.

Table 1. Identified species of leaf miners, their average abundance (number of mines per 100 leaves \pm s.d.) on trees in the urban and rural environments, and effect of habitat type on the frequent species (present in $>20 \%$ samples) assessed by $\mathrm{Z}$ test.

\begin{tabular}{|c|c|c|c|c|c|}
\hline \multirow{2}{*}{ Order } & \multirow{2}{*}{ Family } & \multirow{2}{*}{ Species } & \multicolumn{2}{|c|}{ Abundance } & \multirow{2}{*}{$\begin{array}{l}\text { Significance of the Influence } \\
\text { of the Habitat Type }\end{array}$} \\
\hline & & & Urban & Rural & \\
\hline \multirow{4}{*}{ Coleoptera } & \multirow{4}{*}{ Curculionidae } & Orchestes erythropus (Germ., 1821) & not present & $0.003 \pm 0.040$ & \\
\hline & & O. pilosus (Fabr., 1781) & not present & $0.002 \pm 0.023$ & \\
\hline & & O. quercus (L., 1758) & not present & $0.008 \pm 0.057$ & \\
\hline & & O. subfasciatus Gyll., 1835 & not present & $0.019 \pm 0.094$ & \\
\hline Hymenoptera & Tenthredinidae & Profenusa pygmaea (Klug, 1816) & $0.080 \pm 0.208$ & $0.671 \pm 1.267$ & $Z=-6.81 *$ \\
\hline \multirow{25}{*}{ Lepidoptera } & Bucculatricidae & Bucculatrix ulmella Zell., 1848 & $0.028 \pm 0.141$ & $0.131 \pm 0.333$ & $Z=-2.56^{*}$ \\
\hline & & Coleophora flavipennella (Dup., 1843) & not present & $0.003 \pm 0.039$ & \\
\hline & & C. ibipennella Zell., 1849 & not present & $0.004 \pm 0.043$ & \\
\hline & & C. kuehnella (Goeze, 1783) & not present & $0.007 \pm 0.057$ & \\
\hline & Eriocraniidae & Dyseriocrania subpurpurella (Haw., 1828) & $0.011 \pm 0.069$ & $0.022 \pm 0.113$ & \\
\hline & \multirow{8}{*}{ Gracillariidae } & Acrocercops brongniardella (Fabr., 1798) & $0.021 \pm 0.221$ & $0.007 \pm 0.071$ & \\
\hline & & Caloptilia alchimiella (Scop., 1763) & $0.303 \pm 0.630$ & $2.704 \pm 3.469$ & $Z=-9.66^{*}$ \\
\hline & & Phyllonorycter harrisella (L., 1761) & $2.657 \pm 2.673$ & $1.185 \pm 1.364$ & $Z=5.12$ \\
\hline & & Ph. lautella (Zell., 1846) & not present & $0.015 \pm 0.104$ & \\
\hline & & Ph. messaniella (Zell., 1846) & $0.010 \pm 0.103$ & $0.034 \pm 0.171$ & \\
\hline & & Ph. muelleriella (Zell., 1839) & not present & $0.171 \pm 0.534$ & $\mathrm{n} / \mathrm{a}$ \\
\hline & & Ph. quercifoliella (Zell., 1839) & $0.187 \pm 0.440$ & $0.383 \pm 0.768$ & $Z=-2.13 *$ \\
\hline & & Ph. roboris (Zell., 1839) & $0.206 \pm 0.549$ & $2.981 \pm 4.214$ & $Z^{*}=-9.58 *$ \\
\hline & Heliozelidae & Heliozela sericiella (Haw., 1828) & $0.006 \pm 0.058$ & $0.014 \pm 0.075$ & \\
\hline & \multirow{8}{*}{ Nepticulidae } & Ectoedemia albifasciella (Hein., 1871) & not present & $0.005 \pm 0.043$ & \\
\hline & & E. caradjai (Gros., 1944) & $0.021 \pm 0.122$ & $2.021 \pm 4.171$ & $Z=-6.20 *$ \\
\hline & & E. quinquella (Bed., 1848) & not present & $0.013 \pm 0.122$ & \\
\hline & & E. subbimaculella (Haw., 1828) & not present & $0.034 \pm 0.257$ & \\
\hline & & Stigmella atricapitella (Haw., 1828) & $0.033 \pm 0.189$ & $0.009 \pm 0.083$ & \\
\hline & & S. basiguttella (Hein., 1862) & $0.004 \pm 0.053$ & $0.333 \pm 0.758$ & $Z=-5.03 *$ \\
\hline & & S. roborella (Johan., 1971) & $0.006 \pm 0.067$ & $0.021 \pm 0.132$ & \\
\hline & & S. ruficapitella (Haw., 1828) & $0.018 \pm 0.146$ & $0.010 \pm 0.089$ & \\
\hline & \multirow{3}{*}{ Tischeriidae } & Tischeria decidua Wck., 1876 & $0.050 \pm 0.196$ & $0.316 \pm 0.577$ & $Z=-4.57^{*}$ \\
\hline & & T.dodonaea Stt., 1858 & $0.109 \pm 0.595$ & $0.094 \pm 0.280$ & $Z=-0.43^{\mathrm{ns}}$ \\
\hline & & T. ekebladella (Bjerk., 1795) & $0.189 \pm 0.461$ & $5.155 \pm 6.123$ & $Z=-12.37 *$ \\
\hline
\end{tabular}

Bold names and values indicate frequent species (present in $>20 \%$ of samples); statistically significant differences at the $p \leq 0.05$ significance level are marked ${ }^{*}$; statistically not significant differences $(p>0.05)$ are marked ${ }^{\text {ns }}$; in the cases where the species is present only in one habitat type and the statistical test cannot be applied it is mark $\mathrm{n} / \mathrm{a}$.

\subsection{Leaf Miner Community and Individual Species of Leaf Miners in Urban and Rural Habitats}

Habitat type had a significant effect on pedunculate oak leaf miners' species richness, abundance, and diversity. Species richness was about 2.5, abundance about four, and diversity about 2.5 times lower than that recorded on trees in the rural environment (Tables 1-3; Figures 1 and 2). Of the 12 analyzed species that were found in both habitat types, 10 had a significantly lower frequency of occurrence and abundance in the urban environment (Table 1). Tischeria dodonaea (Stainton, 1858) was not influenced by the habitat type, while Ph. harrisella was more frequent and abundant in the urban environment (Table 1). The species that were not present on trees in the urban environment (12) (except for Phyllonorycter mueleriella (Zeller, 1839)) had a low frequency of occurrence and abundance in the rural environment (Table 1). Despite all the altered habitat characteristics, $60 \%$ of leaf miners' species survived in the urban environment. However, they survived with a significantly lower abundance and frequency of occurrence (Table 1). 
Table 2. Effect of habitat type on total species richness, abundance, and diversity assessed by Mann-Whitney $U$ test ( $U$ and $Z$ are measures of the significance of the difference between the samples, based on the sum of ranks and distance from the mean; $N$ is the number of the samples (trees) analyzed).

\begin{tabular}{cccccccc}
\hline $\begin{array}{c}\text { Analyzed } \\
\text { Parameter }\end{array}$ & $\begin{array}{c}\text { Rank Sum } \\
\text { Urban Habitat }\end{array}$ & $\begin{array}{c}\text { Rank Sum } \\
\text { Rural Habitat }\end{array}$ & U & Z & - -Level & $\begin{array}{c}\text { Valid N Urban } \\
\text { Habitat }\end{array}$ & $\begin{array}{c}\text { Valid N Rural } \\
\text { Habitat }\end{array}$ \\
\hline $\begin{array}{c}\text { Species } \\
\text { richness }\end{array}$ & $25,491.5$ & $48,428.5$ & 6963.5 & -10.546 & 0.000 & 192 & 192 \\
Abundance & $26,995.5$ & $46,924.5$ & 8467.5 & -9.163 & 0.000 & 192 & 192 \\
Diversity & $24,828.5$ & $49,091.5$ & 6300.5 & -11.155 & 0.000 & 192 & 192 \\
\hline
\end{tabular}

Table 3. Effect of habitat type and individual months of the vegetative season on species richness, abundance, and diversity, assessed by the Mann-Whitney $U$ test ( $U$ and $Z$ are measures of the significance of the difference between the samples, based on the sum of ranks and distance from the mean; $\mathrm{N}$ is the number of the samples (trees) analyzed).

\begin{tabular}{|c|c|c|c|c|c|c|c|c|c|}
\hline $\begin{array}{l}\text { Analyzed } \\
\text { Parameter }\end{array}$ & Month & $\begin{array}{c}\text { Rank Sum } \\
\text { Urban Habitat }\end{array}$ & $\begin{array}{c}\text { Rank Sum } \\
\text { Rural Habitat }\end{array}$ & $\mathbf{U}$ & $\mathbf{Z}$ & $p$-Level & $\begin{array}{c}\text { Valid N Urban } \\
\text { Habitat }\end{array}$ & $\begin{array}{c}\text { Valid N Rural } \\
\text { Habitat }\end{array}$ & $\begin{array}{c}2 * 1 \text { Sided } \\
\text { Exact } p\end{array}$ \\
\hline \multirow{6}{*}{$\begin{array}{c}\text { Species } \\
\text { Richness }\end{array}$} & May & 910.0 & 1170.0 & 382.0 & -1.746 & 0.081 & 32 & 32 & 0.082 \\
\hline & June & 551.5 & 1528.5 & 23.5 & -6.559 & 0.000 & 32 & 32 & 0.000 \\
\hline & July & 528.0 & 1552.0 & 0.0 & -6.875 & 0.000 & 32 & 32 & 0.000 \\
\hline & August & 660.5 & 1419.5 & 132.5 & -5.096 & 0.000 & 32 & 32 & 0.000 \\
\hline & September & 631.5 & 1448.5 & 103.5 & -5.485 & 0.000 & 32 & 32 & 0.000 \\
\hline & October & 609.5 & 1470.5 & 81.5 & -5.780 & 0.000 & 32 & 32 & 0.000 \\
\hline \multirow{5}{*}{ Abundance } & June & 550.0 & 1530.0 & 22.0 & -6.579 & 0.000 & 32 & 32 & 0.000 \\
\hline & July & 633.0 & 1447.0 & 105.0 & -5.465 & 0.000 & 32 & 32 & 0.000 \\
\hline & August & 652.0 & 1428.0 & 124.0 & -5.210 & 0.000 & 32 & 32 & 0.000 \\
\hline & September & 625.0 & 1455.0 & 97.0 & -5.572 & 0.000 & 32 & 32 & 0.000 \\
\hline & October & 594.5 & 1485.5 & 66.5 & -5.982 & 0.000 & 32 & 32 & 0.000 \\
\hline \multirow{2}{*}{ Diversity } & May & 941.5 & 1138.5 & 413.5 & -1.323 & 0.186 & 32 & 32 & 0.187 \\
\hline & October & 652.5 & 1427.5 & 124.5 & -5.203 & 0.000 & 32 & 32 & 0.000 \\
\hline
\end{tabular}

Italic values indicate statistically significant differences, at the level of significance $p \leq 0.05$.

\subsection{Seasonal Dynamics of Leaf Miners' Species Richness, Abundance, and Diversity}

Species richness, abundance, and diversity differed significantly between the months of the vegetative season in the urban, as well as in the rural, environment (Table 4, Figure 2). Habitat type significantly influenced the species richness, abundance, and diversity throughout the vegetative season (Table 3, Figure 2). The analyzed parameters were not influenced by habitat type only in May (Table 3, Figure 2). They were significantly lower in the urban environment in all the subsequent months (Table 3, Figure 2). Species richness and abundance culminated in August in both habitat types (Figure 2a,b). Species richness steadily increased until the point of culmination and maintained similar values until the end of the vegetative season (Figure 2a). Abundance arose multiple times during the vegetative season, first in June, then in August, and once more, questionably, in October (Figure $2 b$ ). These peaks are less noticeable in the urban environment due to the lower recorded values. Diversity culminated earlier in the rural environment (July) than in the urban environment (August) and maintained similar values until the end of the vegetative season afterward (Table 3, Figure 2c). While values of species richness per tree were similar in May, total species richness in the investigated areas was constantly higher in the rural environment (Table 5). 

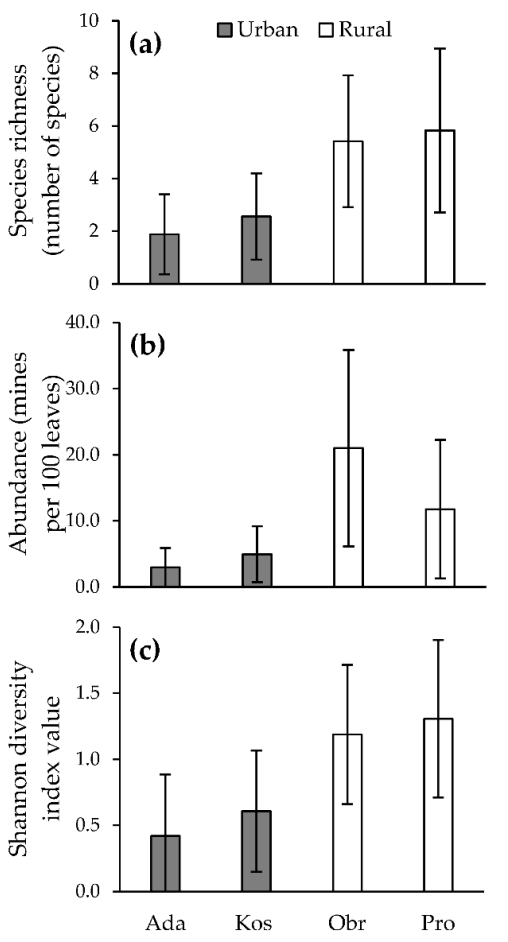

Figure 1. Effect of study site and habitat type on: (a) species richness, (b) abundance, (c) diversity of leaf miners (mean \pm s.d.) (Ada = Ada Ciganlija, Kos = Košutnjak, Obr = Obrež, Pro = Progar).
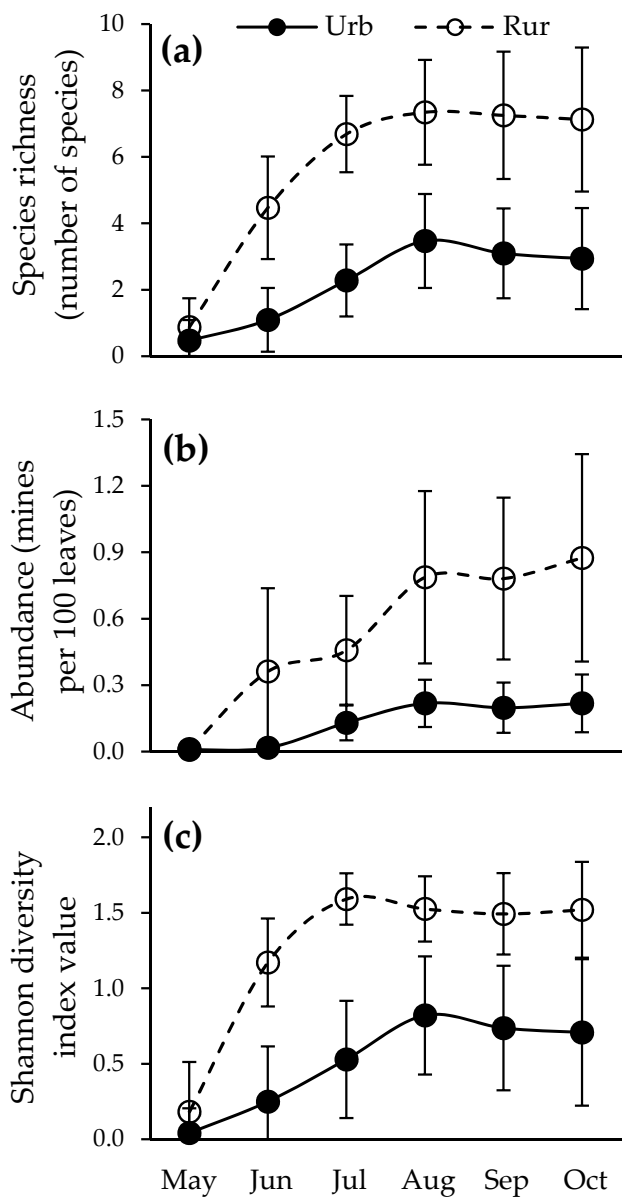

Figure 2. Seasonal dynamics of leaf miners: (a) species richness, (b) abundance, (c) diversity (mean \pm s.d.) on trees in the urban and rural environments (Urb = Urban habitat; Rur = Rural habitat). 
Table 4. Effect of month of the vegetative season on species richness, abundance, and diversity in urban and rural habitats, assessed by Friedman ANOVA ( $\mathrm{N}$ is the number of the samples (trees) analyzed).

\begin{tabular}{|c|c|c|c|c|c|}
\hline Analyzed Parameter & Habitat Type & $\mathbf{N}$ & $\overline{D f}$ & Chi Sqr. & $p$ \\
\hline \multirow{2}{*}{ Species richness } & Urban & \multirow{6}{*}{32} & \multirow{6}{*}{5} & 97.154 & 0.000 \\
\hline & Rural & & & 94.391 & 0.000 \\
\hline & Urban & & & 122.455 & 0.000 \\
\hline Abundance & Rural & & & 109.589 & 0.000 \\
\hline \multirow{2}{*}{ Diversity } & Urban & & & 65.428 & 0.000 \\
\hline & Rural & & & 89.459 & 0.000 \\
\hline
\end{tabular}

Table 5. Species identified per habitat type per month.

\begin{tabular}{|c|c|c|c|c|c|c|c|c|c|c|c|c|}
\hline \multirow{2}{*}{ Species } & \multicolumn{2}{|c|}{ May } & \multicolumn{2}{|c|}{ Jun } & \multicolumn{2}{|c|}{ Jul } & \multicolumn{2}{|c|}{ Aug } & \multicolumn{2}{|c|}{ Sep } & \multicolumn{2}{|c|}{ Oct } \\
\hline & $\mathbf{U}$ & $\mathbf{R}$ & $\mathbf{U}$ & $\mathbf{R}$ & $\mathbf{U}$ & $\mathbf{R}$ & $\mathbf{U}$ & $\mathbf{R}$ & $\mathbf{U}$ & $\mathbf{R}$ & $\mathbf{U}$ & $\mathbf{R}$ \\
\hline Orchestes erythropus (Germ., 1821) & & & & + & & & & & & & & \\
\hline O. pilosus (Fabr., 1781) & & + & & & & & & & & & & \\
\hline O. quercus (L., 1758) & & + & & + & & & & & & & & \\
\hline O. subfasciatus Gyll., 1835 & & + & & + & & + & & & & & & \\
\hline Profenusa pygmaea (Klug, 1816) & + & + & + & + & + & + & + & + & + & + & + & + \\
\hline Bucculatrix ulmella Zell., 1848 & & & & + & + & + & + & + & + & + & + & + \\
\hline Coleophora flavipennella (Dup., 1843) & & + & & & & & & & & & & \\
\hline C. ibipennella Zell., 1849 & & & & & & + & & & & & & \\
\hline C. kuehnella (Goeze, 1783) & & + & & & & + & & + & & & & \\
\hline Dyseriocrania subpurpurella (Haw., 1828) & + & + & + & + & + & + & & & & & & \\
\hline Acrocercops brongniardella (Fabr., 1798) & & & & + & & & & & & + & + & \\
\hline Caloptilia alchimiella (Scop., 1763) & & + & & + & + & + & + & + & + & + & + & + \\
\hline Phyllonorycter harrisella (L., 1761) & + & + & + & + & + & + & + & + & + & + & + & + \\
\hline Ph. lautella (Zell., 1846) & & & & + & & & & & & + & & \\
\hline Ph. messaniella (Zell., 1846) & & & & & & & + & + & & & & \\
\hline Ph. muelleriella (Zell., 1839) & & & & + & & + & & + & & + & & + \\
\hline Ph. quercifoliella (Zell., 1839) & + & + & + & + & + & + & + & + & + & + & + & + \\
\hline Ph. roboris (Zell., 1839) & & & + & + & + & + & + & + & + & + & + & + \\
\hline Heliozela sericiella (Haw., 1828) & + & + & & & + & + & & & & + & & \\
\hline Ectoedemia albifasciella (Hein., 1871) & & & & & & + & & + & & & & \\
\hline E. caradjai (Gros., 1944) & & & & & & + & & + & + & + & + & + \\
\hline E. quinquella (Bed., 1848) & & & & & & & & & & & & + \\
\hline E. subbimaculella (Haw., 1828) & & & & & & & & & & & & + \\
\hline Stigmella atricapitella (Haw., 1828) & & & & & + & & & & + & & + & + \\
\hline S. basiguttella (Hein., 1862) & & & & + & & + & & + & & + & + & + \\
\hline S. roborella (Johan., 1971) & & & + & + & & + & & & + & + & & + \\
\hline S. ruficapitella (Haw., 1828) & & + & & & & & + & + & & & + & + \\
\hline Tischeria decidua Wck., 1876 & & & & + & + & + & + & + & + & + & + & + \\
\hline T.dodonaea Stt., 1858 & & & & & & + & + & + & + & + & + & + \\
\hline T. ekebladella (Bjerk., 1795) & & & & + & + & + & + & + & + & + & + & + \\
\hline Total species per habitat type per month & 5 & 12 & 6 & 17 & 11 & 19 & 11 & 16 & 12 & 16 & 14 & 17 \\
\hline
\end{tabular}

\section{Discussion}

In this study, we determined a significant influence of the habitat type on the leaf miner community. Considerably lower species richness, abundance, and diversity were recorded in the urban environment in all the months of the vegetative season except for May. Most of the dominant species that were present in both habitat types had a significantly lower abundance and frequency of occurrence in the urban environment. T. dodonaea was unaffected by the habitat type, and Ph. harrisella even had higher values in the urban environment. However, neither Rickman and Connor nor Moreira et al. $[9,16]$ 
determined an influence of habitat type on the leaf miner community. On the other hand, Rickman and Connor [9] found that some individual species can have higher and some lower abundance in the urban environment, as determined similarly in our study. A decline in species richness and abundance in the urban environment has also been recorded in other insect species, such as ants in developing residential areas in the USA [24], sarcophagid Diptera in rural-urban gradient in Buenos Aires [48], butterflies in urban green areas in South Korea [27], as well as in many other specialist insect communities [11]. The decline in the leaf miners' diversity in urban habitats is also consistent with the results of the studies on other insect species. Invertebrate diversity declines in the urban environment in $64 \%$ of the cases. It is higher in the urban environment in $30 \%$, while it does not differ from rural habitats in $6 \%$ of the cases [64].

Many of the species that had a low frequency of occurrence and abundance in the rural environment were not recorded in the urban environment. The majority of species that were most frequent and abundant in the rural environment had considerably lower abundance in the urban environment. According to Eötvös et al. and Denys and Schmidt $[19,28]$, the disappearance of specialist species from the urban environment is a common consequence of urbanization, so it is not surprising that many leaf miner species reacted like this. Most of the species that were most frequent and abundant in the rural environment did not adapt to the altered conditions in the urban environment successfully. However, not all species in this study responded in the same manner to the differences between the habitat types. Two species-Ph. harrisella (the most frequent species in the study) and T. dodonaea-were able to adapt to the altered conditions in the urban environment successfully. The difference in the habitat conditions did not have a considerable influence only on T. dodonaea, while Ph. harrisella was even more frequent and abundant in the urban environment.

The urban environment where the research was conducted is considerably anthropogenically altered. Here, the pedunculate oak trees are present in small, isolated fragments. The differences in landscape-level factors between urban and rural areas most often influence the leaf miners' abundance $[9,16]$. Of these landscape-level factors, fragmentation and reduction in habitat area are the most significant. The influence of these two factors is most frequently negative $[9,15,28,65]$. However, some consider this impact to be positive [66-68] or neutral $[54,66]$. The negative influence of these factors determined in our study can be explained by several key differences between habitat types. The analyzed pedunculate oak trees were more isolated in the urban environment. They composed separated groups of four to nine trees and were surrounded by groups of other autochthonous and allochthonous tree species, open areas with herbaceous vegetation, roads, and other anthropogenically altered surfaces. The greater diversity of surrounding woody plants in the urban environment might have negatively influenced the leaf miners' community [54,69-71]. The intensity of chemical and visual cues in these smaller, isolated groups of trees is considerably lower than that in the rural pure, dense oak stands present in the rural environment $[67,68]$. This is why leaf miners have a harder time finding suitable hosts. Leaf miners are weak flyers [9,56,57] so they are not successful at colonizing the scattered fragments where pedunculate oak is present in the urban environment $[68,72]$. Many atmospheric factors are also frequently altered in the urban environment, compared to the rural one. Specifically, an increase in temperature and $\mathrm{CO}_{2}$ concentration are often emphasized as the most important ones $[16,28,44]$. However, the temperature differences between urban and rural areas in this study did not exceed the thermal safety limit of insect herbivores living in temperate areas of $3.5^{\circ} \mathrm{C}$ [16]. As the temperature was not measured at the exact location of the investigated trees, we cannot definitely exclude its influence on the leaf miner community. The effects of $\mathrm{CO}_{2}$ were not estimated in this study, but Moreira et al. [16] concluded that even doubled concentrations in urban areas do not have a significant influence on leaf miners. On the other hand, microclimate conditions of the individual leaves can have an influence on the leaf feeding insects [73]. As the canopy cover was significantly reduced in the urban environment, the leaves on those trees were more exposed to direct sunlight. The increased temperature and lower humidity of the sun-exposed leaves [73] could have influenced the leaf miner mortality. As leaf miners are closely connected 
with the leaf tissue during their larval development [35,37], it would be expected that the changes in leaf traits caused by altered habitat characteristics would influence them. However, no influence of chemical nor morphological leaf traits on the leaf miners' community was determined in previous studies $[16,23,46,54]$. Another plant trait that could have potentially affected the leaf miners in the urban environment is premature leaf abscission $[74,75]$. Namely, when soil characteristics and canopy cover are significantly disturbed [21,23,76,77], as in the investigated localities, plants are exposed to drought stress, so they react by prematurely, abscising the leaves damaged by the leaf miners $[18,74-76,78]$. The larvae in those abscised leaves frequently cannot finish their development, so the mortality levels increase further [74].

Considerable variation in species richness, abundance, and diversity of leaf miners was recorded during the vegetative season in both urban and rural environments. While the impact of the differences between urban and rural habitats on the leaf miners' seasonality has never been studied, previous studies on the seasonality of their natural populations on pedunculate oak found a similar pattern such as the one determined in our study. The measured parameters were lowest at the beginning of the vegetative season, and were significantly higher in the latter part of the vegetative season [41,79]. According to Southwood et al. [73], the culmination of leaf miner abundance in August is an evolutionary trait that they developed to avoid the period of early spring. During that period, a large number of defoliators that can eat the leaves on which they develop is present [73,75]. Multiple peaks in abundance during the vegetative season were recorded in our research. This can be attributed to the fact that the majority of the most frequent and most abundant species of leaf miners such as Ph. harrisella, T. ekebladella, Ph. roboris, and Ph quercifoliella have multiple generations per vegetative season $[49,76]$. The questionable peak in abundance in October can be attributed to the fact that the mined leaves generally remain on the tree longer than the unmined ones [79]. While abundance had multiple peaks during the vegetative season, species richness steadily increased until the moment when all the identified species had already appeared. The reason for the slight decline in species richness after the culmination is that some species such as P. pygmaea and C. alchimiella had only one generation earlier in the season.

The values of species richness, abundance, and diversity were similar in the urban and rural environments only at the beginning of the vegetative season. All parameters increased rapidly after May and were considerably higher in the rural environment in the subsequent months. The most favorable explanation for the considerably higher species richness, abundance, and diversity in the rural environment in the months after May is that the leaf miner abundance decreased with a decrease in the participation of host trees in the tree mixture [80,81]. The host trees in the urban environment were scattered in groups, whereas pedunculate oak was present as the dominant species in dense forests in the rural environment. Most of the determined frequent and abundant species are multivoltine, so they might have had a harder time finding the suitable host trees for the development of the second generation. Even if some females had found a suitable leaf for laying their eggs, the fate of those larvae might have already been predetermined, as the drought-stressed plants tend to abscise the damaged leaves [74,75]. The differences in abundance and species richness during the vegetative season can also be explained by the fact that the investigated localities in the urban environment are treated for ticks and mosquitos every spring, so some species might have reacted to those pesticides. While some of them might have died from exposure to the insecticides, others might have migrated to the upper parts of the crown that were not reached by the insecticide treatment. Because of this, they might have not been detected in the analyzed samples, as the leaves were sampled up to a height of $8 \mathrm{~m}$. Human activity in the urban areas during the summer months could have also driven the leaf miners to the higher parts of the crown, where the leaves frequently contain a higher level of nutrients [82]. According to Valencia-Cuevas and Tovar-Sánchez [83], there is a lack of literature that addresses the study of habitat preference of arthropod communities associated with the oak canopies, so this should be looked into with greater attention. The earlier culmination of diversity in the rural environment is a consequence of the fact that most of the rare species have already appeared by that moment, 
and the abundance culminated in the following month. At the moment of culmination of abundance, the presence of the most dominant and abundant species (the five of them that caused $85 \%$ of the total number of mines) increased, and the participation of rarer species in the community decreased. As the Shannon diversity index value is largely influenced by the evenness of participation of all species in the community $[84,85]$, the diversity was lower after the culmination of abundance. In the urban environment, the abundance of the majority of these most frequent and most abundant species was substantially lower, so the diversity culminated at the same time as species richness and abundance.

Pedunculate oak trees in the urban environment are of great importance as a species reservoir because $60 \%$ of the leaf miners' species identified in this study survived on them. As their abundance is significantly lower than the abundance of the species identified in the rural habitat, their survival on those trees is questionable because their populations are less stable [86,87]. This is why we should preserve and improve the state of these urban green areas, which are gaining increasing importance with the process of urbanization $[13,35]$. Although it has been found that the habitat type has a significant influence on the leaf miners' community, further research is needed to determine how, and which individual factors affect this group of insects.

\section{Conclusions}

Habitat type considerably influences the pedunculate oak leaf miners' community. This influence is presented by the changes in species richness, frequency of occurrence, abundance, diversity, as well as in seasonal dynamics. Considerably lower species richness, abundance, and diversity were recorded on trees in the urban habitats. Of all the identified leaf miners, abundance and frequency of occurrence of only one species were higher in the urban environment, while one species was not affected by habitat type. Species richness, abundance, and diversity were similar in the urban and rural environments only in May, while they were considerably higher in the rural environment in all of the subsequent months. These differences can be mostly contributed to the landscape factors, but further research is needed to determine how, and which individual factors that differ between urban and rural habitats affect this group of insects. Despite the impact of habitat type, a great number $(60 \%)$ of the species of leaf miners survive in urban habitats. Because of this, the pedunculate oak trees in the urban environment are of particular importance as a species reservoir, and we need to preserve them and strive to improve the condition of urban areas in which they are present.

Supplementary Materials: The following are available online at http://www.mdpi.com/1999-4907/11/12/1300/s1, Figure S1: Map of the investigated localities.

Author Contributions: Conceptualization, J.D.; Methodology, J.D. and S.M.; Validation, J.D., Č.M., M.M. and S.M.; Formal Analysis, J.D., and S.M.; Investigation, J.D., Č.M. and M.M.; Resources, J.D., Č.M. and M.M.; Data Curation, J.D.; Writing—Original Draft Preparation, J.D.; Writing—Review and Editing, J.D., Č.M., M.M. and S.M.; Visualization, J.D. and S.M.; Supervision, Č.M. and S.M.; Project Administration, J.D.; Funding Acquisition, J.D., Č.M., M.M. and S.M. All authors have read and agreed to the published version of the manuscript.

Funding: We would like to thank the Serbian Ministry of Education, Science and Technological Development, grant number 451-02-68/2020/14/2000169, for financing scientific research at the Faculty of Forestry University of Belgrade in 2020.

Conflicts of Interest: The authors declare no conflict of interest.

\section{References}

1. Primack, R. Where is the World's Biological Diversity Found? In Essentials of Conservation Biology; Primack, R., Ed.; Sinauer Associates, Inc.: Sunderland, MA, USA, 2014; pp. 51-68. ISBN 978-1605352893.

2. Brockerhoff, E.G.; Barbaro, L.; Castagneyrol, B.; Forrester, D.I.; Gardiner, B.; González-Olabarria, J.R.; Lyver, P.O.B.; Meurisse, N.; Oxbrough, A.; Taki, H.; et al. Forest biodiversity, ecosystem functioning and the provision of ecosystem services. Biodivers. Conserv. 2017, 26, 3005-3035. [CrossRef]

3. DeFries, R.S.; Rudel, T.; Uriarte, M.; Hansen, M. Deforestation driven by urban population growth and agricultural trade in the twenty-first century. Nat. Geosci. 2010, 3, 178-181. [CrossRef] 
4. Eltom, I.M.; Elfaig, A.H.I.; Salih, A.A.M. Urban Development and Deforestation: Urban Development and Deforestation: Evidences from El-Obeid Town (1970-2010), Western Sudan. Int. J. Sci. Res. Publ. 2013, 3, 1-9.

5. Sejati, A.W.; Buchori, I.; Rudiarto, I. The Impact of Urbanization to Forest Degradation in Metropolitan Semarang: A Preliminary Study. IOP Conf. Ser. Earth Environ. Sci. 2018, 123, 012011. [CrossRef]

6. FAO. Global Forest Resources Assessment 2020; FAO: Rome, Italy, 2020; ISBN 978-92-5-132974-0.

7. Contreras-Hermosilla, A. The Underlying Causes of Forest Decline. CIFOR Occas. Pap. 2000, 30, 1-25.

8. Wheeler, A.G. College Campuses: Patches of Insect Diversity, Opportunities for Entomological Discovery, and Means for Enhancing Ecological Literacy. Am. Entomol. 2008, 54, 18-35. [CrossRef]

9. Rickman, J.K.; Connor, E.F. The effect of urbanization on the quality of remnant habitats for leaf-mining Lepidoptera on Quercus agrifolia. Ecography 2003, 26, 777-787. [CrossRef]

10. Hunter, P. The human impact on biological diversity: How species adapt to urban challenges sheds light on evolution and provides clues about conservation. EMBO Rep. 2007, 8, 316-318. [CrossRef]

11. Ye, S.; Fang, Y.; Li, K. Impacts of urbanization process on insect diversity. Biodivers. Sci. 2013, 21, $260-268$. [CrossRef]

12. Su, Z.; Li, X.; Zhou, W.; Ouyang, Z. Effect of Landscape Pattern on Insect Species Density within Urban Green Spaces in Beijing, China. PLoS ONE 2015, 10, e0119276. [CrossRef]

13. Aronson, M.F.J.; Lepczyk, C.A.; Evans, K.L.; Goddard, M.A.; Lerman, S.B.; MacIvor, J.S.; Nilon, C.H.; Vargo, T. Biodiversity in the city: Key challenges for urban green space management. Front. Ecol. Environ. 2017, 15, 189-196. [CrossRef]

14. Mata, L.; Threlfall, C.G.; Williams, N.S.G.; Hahs, A.K.; Malipatil, M.; Stork, N.E.; Livesley, S.J. Conserving herbivorous and predatory insects in urban green spaces. Sci. Rep. 2017, 7, 40970. [CrossRef] [PubMed]

15. Tu, T.H.; Wang, J.R.; Gu, J.Q.; Li, T.Q.; Lv, K.; Zhou, G.X.; Xu, Z.H. Effects of habitat fragmentation on the functional diversity of insects in Thousand Island Lake, China. Entomol. Res. 2019, 49, 93-104. [CrossRef]

16. Moreira, X.; Abdala-Roberts, L.; Berny Mier y Teran, J.C.; Covelo, F.; de la Mata, R.; Francisco, M.; Hardwick, B.; Pires, R.M.; Roslin, T.; Schigel, D.S.; et al. Impacts of urbanization on insect herbivory and plant defences in oak trees. Oikos 2019, 128, 113-123. [CrossRef]

17. Herrmann, D.L.; Pearse, I.S.; Baty, J.H. Drivers of specialist herbivore diversity across 10 cities. Landsc. Urban Plan. 2012, 108, 123-130. [CrossRef]

18. McIntyre, N.E. Ecology of Urban Arthropods: A Review and a Call to Action. Ecol. Popul. Biol. 2000, 93, 825-835. [CrossRef]

19. Eötvös, C.B.; Lövei, G.L.; Magura, T. Predation Pressure on Sentinel Insect Prey Along a Riverside Urbanization Gradient in Hungary. Insects 2020, 11, 97. [CrossRef]

20. Li, D.; Stucky, B.J.; Deck, J.; Baiser, B.; Guralnick, R.P. The effect of urbanization on plant phenology depends on regional temperature. Nat. Ecol. Evol. 2019, 3, 1661-1667. [CrossRef]

21. Jaworski, T.; Hilszczański, J. The effect of temperature and humidity changes on insects development their impact on forest ecosystems in the expected climate change. For. Res. Pap. 2014, 74, 345-355. [CrossRef]

22. Bale, J.S.; Masters, G.J.; Hodkinson, I.D.; Awmack, C.; Bezemer, T.M.; Brown, V.K.; Butterfield, J.; Buse, A.; Coulson, J.C.; Farrar, J.; et al. Herbivory in global climate change research: Direct effects of rising temperature on insect herbivores. Glob. Chang. Biol. 2002, 8, 1-16. [CrossRef]

23. Kozlov, M.V.; Lanta, V.; Zverev, V.; Rainio, K.; Kunavin, M.A.; Zvereva, E.L. Decreased losses of woody plant foliage to insects in large urban areas are explained by bird predation. Glob. Chang. Biol. 2017, 23, 4354-4364. [CrossRef] [PubMed]

24. Buczkowski, G.; Richmond, D.S. The Effect of Urbanization on Ant Abundance and Diversity: A Temporal Examination of Factors Affecting Biodiversity. PLoS ONE 2012, 7, e41729. [CrossRef] [PubMed]

25. McIntyre, N.E.; Rango, J.; Fagan, W.F.; Faeth, S.H. Ground arthropod community structure in a heterogeneous urban environment. Landsc. Urban Plan. 2001, 52, 257-274. [CrossRef]

26. Eötvös, C.B.; Magura, T.; Lövei, G.L. A meta-analysis indicates reduced predation pressure with increasing urbanization. Landsc. Urban Plan. 2018, 180, 54-59. [CrossRef]

27. Lee, C.M.; Park, J.W.; Kwon, T.S.; Kim, S.S.; Ryu, J.W.; Jung, S.J.; Lee, S.K. Diversity and density of butterfly communities in urban green areas: An analytical approach using GIS. Zool. Stud. 2015, 54, 1-12. [CrossRef]

28. Denys, C.; Schmidt, H. Insect communities on experimental mugwort (Artemisia vulgaris L.) plots along an urban gradient. Oecologia 1998, 113, 269-277. [CrossRef]

29. Hering, E.M. Biology of the Leaf Miners; Dr W. Junk: Hague, The Netherlands, 1951. 
30. Hering, E.M. Bestimmungstabellen der Blattminen von Europa Einschliesslich des Mittelmeerbeckens und der Kanarishen Inseln, Band I, II und III; Dr W. Junk: Hague, The Netherlands, 1957; ISBN ISBN 9789061939818.

31. Brändle, M.; Amarell, U.; Auge, H.; Klotz, S.; Brandl, R. Plant and insect diversity along a pollution gradient: Understanding species richness across trophic levels. Biodivers. Conserv. 2001, 10, 1497-1511. [CrossRef]

32. Ali, J.G.; Agrawal, A.A. Specialist versus generalist insect herbivores and plant defense. Trends Plant Sci. 2012, 17, 293-302. [CrossRef]

33. Nakadai, R. Species diversity of herbivorous insects: A brief review to bridge the gap between theories focusing on the generation and maintenance of diversity. Ecol. Res. 2017, 32, 811-819. [CrossRef]

34. Weisser, W.; Siemann, E. The Various Effects of Insects on Ecosystem Functioning. In Insects and Ecosystem Function; Weisser, W., Siemann, E., Eds.; Springer: Berlin/Heidelberg, Germany, 2008; pp. 3-24. ISBN 978-3-540-74004-9.

35. Jones, E.L.; Leather, S.R. Invertebrates in urban areas: A review. Eur. J. Entomol. 2012, 109, $463-478$. [CrossRef]

36. Siddig, A.A.H.; Ellison, A.M.; Ochs, A.; Villar-leeman, C.; Lau, M.K. How do ecologists select and use indicator species to monitor ecological change? Insights from 14 years of publication in Ecological Indicators. Ecol. Indic. 2016, 60, 223-230. [CrossRef]

37. Atkinson, B.; Bailey, S.; Vaughan, I.P.; Memmott, J. A comparison of clearfelling and gradual thinning of plantations for the restoration of insect herbivores and woodland plants. J. Appl. Ecol. 2015, 52, 1538-1546. [CrossRef]

38. Dobrosavljevic, J.; Markovic, C.; Bojic, S. Overview of leaf miner fauna in Serbia. In Proceedings of the VIII International Agriculture Symposium "AGROSYM 2017"; Kovacevic, D., Ed.; University of East Sarajevo, Faculty of Agriculture, Republic of Srpska, Bosnia: Jahorina, Bosnia and Herzegovina, 2018; pp. 1490-1498.

39. Dobrosavljević, J.; Marković, Č. Hinatara nigripes (Konow) i Heterarthrus flavicollis (Gussakovskij) (Hymenoptera, Tenthredinidae), nove vrste lisnih minera u fauni Srbije. In Proceedings of the XI Simpozijum Entomologa Srbije; Glavendekić, M., Ed.; Entomološko Društvo Srbije: Goč, Serbia, 2017; pp. 79-80.

40. Dobrosavljević, J.N.; Marković, Č.; Stojanović, A. Contribution To the Knowledge of Phyllonorycter issikii (Kumata, 1963) (Lepidoptera, Gracillariidae) in Serbia. Acta Entomol. Serbica 2018, 23, 25-32. [CrossRef]

41. Marković, Č.; Dobrosavljević, J.; Vujičić, P.; Cebeci, H.H. Impact of regeneration by shelterwood cutting on the pedunculate oak (Quercus robur) leaf mining insect community. Biologia 2020. [CrossRef]

42. Simonović, M.; Gaora, D. Miner vinove loze, Phyllocnistis vitegenella Clemens (Lepidoptera: Gracillariidae)—Nova vrsta u Srbiji. Biljn. Lek. 2019, 47, 337-344.

43. Raupp, M.J.; Shrewsbury, P.M.; Herms, D.A. Ecology of Herbivorous Arthropods in Urban Landscapes. Annu. Rev. Entomol. 2010, 55, 19-38. [CrossRef]

44. Fenoglio, M.S.; Salvo, A.; Estallo, E.L. Effects of urbanisation on the parasitoid community of a leafminer. Acta Oecol. 2009, 35, 318-326. [CrossRef]

45. Kahn, D.M.; Cornell, H.V. Leafminers, Early Leaf Abscission, and Parasitoids: A Tritrophic Interaction. Ecology 1989, 70, 1219-1226. [CrossRef]

46. Koricheva, J.; Larsson, S.; Haukioja, E. Insect Performance on Experimentally Stressed Woody Plants: A Meta-Analysis. Annu. Rev. Entomol. 1998, 43, 195-216. [CrossRef]

47. Oke, T.R. City size and the urban heat island. Atmos. Environ. 1973, 7, 769-779. [CrossRef]

48. Mulieri, P.R.; Patitucci, L.D.; Schnack, J.A.; Mariluis, J.C. Diversity and seasonal dynamics of an assemblage of sarcophagid diptera in a gradient of urbanization. J. Insect Sci. 2011, 11, 1-15. [CrossRef] [PubMed]

49. Magura, T.; Lövei, G.L. The permeability of natural versus anthropogenic forest edges modulates the abundance of ground beetles of different dispersal power and habitat affinity. Diversity 2020, 12, 320. [CrossRef]

50. Eaton, E.; Caudullo, G.; Oliveira, S.; de Rigo, D. Quercus robur and Quercus petraea in Europe: Distribution, habitat, usage and threats. In European Atlas of Forest Tree Species; San-Miguel-Ayanz, J., de Rigo, D., Caudullo, G., Houston Durrant, T., Mauri, A., Eds.; Publication Office of the European Union: Luxembourg, 2016; pp. 160-163. ISBN 978-92-79-52833-0.

51. Annighöfer, P.; Beckschäfer, P.; Vor, T.; Ammer, C. Regeneration Patterns of European Oak Species (Quercus petraea (Matt.) Liebl., Quercus robur L.) in Dependence of Environment and Neighborhood. PLoS ONE 2015, 10, e0134935. [CrossRef] [PubMed] 
52. Quine, C.; Atkinson, N.; Denman, S.; Desprez-loustau, L.; Jackson, R.; Kirby, K. Action Oak Knowledge Review: An Assessment of the Current Evidence on Oak Health, Identification of Evidence Gaps and Prioritisation of Research Needs; Atkinson, N., Desprez-Loustau, M.-L., Kirby, K., Denman, S., Jackson, R., Quine, C., Eds.; Action Oak: Haslemere, UK, 2019; ISBN 978-1-5272-4193-0.

53. Pearson, D.L. Selecting indicator taxa for the quantitative assessment of biodiversity. Biodivers. Meas. Estim. 1995, 345, 75-79.

54. Barantal, S.; Castagneyrol, B.; Durka, W.; Iason, G.; Morath, S.; Koricheva, J. Contrasting effects of tree species and genetic diversity on the leaf-miner communities associated with silver birch. Oecologia 2019, 189, 687-697. [CrossRef]

55. Ellis, W.N. Leafminers and Plant Galls of Europe. Available online: http://www.bladmineerders.nl/ (accessed on 20 October 2019).

56. Baraniak, E.; Walczak, U.; Tryjanowski, P.; Zduniak, P. Effect of distance between host trees and leaf litter removal on population density of Cameraria ohridella Deschka \& Dimic, 1986 (Lepidoptera, Gracillariidae)—Pest of chestnut (Aesculus sp.) trees. Pol. J. Ecol. 2004, 52, 569-574.

57. Jovicich, E. Leafminer Pest-Generic Incursion Management Plan for the Australian Vegetable Industry; Horticulture Australia Ltd.: Sydney, Australia, 2009; ISBN 0-7341-2154-7. Available online: http://era.daf.qld.gov.au/id/ eprint/2539/ (accessed on 16 March 2017).

58. Da Rocha, J.M.R.; Almeida, J.R.; Lins, G.A.; Durval, A. Insects as indicators of environmental changing and pollution: A review of appropriate species and their monitoring. Holos Environ. 2010, 10, 250-262. [CrossRef]

59. Gerlach, J.; Samways, M.; Pryke, J. Terrestrial invertebrates as bioindicators: An overview of available taxonomic groups. J. Insect Conserv. 2013, 17, 831-850. [CrossRef]

60. Republic Hydrometeorological Service of Serbia. Available online: http://www.hidmet.gov.rs (accessed on 13 May 2020).

61. Forest Directorate of Ministry of Agriculture Forestry and Water Management. Available online: https://upravazasume.gov.rs (accessed on 13 May 2020).

62. Patočka, J.; Turčani, M. Lepidoptera Pupae. Central European Species; Apollo Books: Stenstrup, Denmark, 2005; ISBN 9788788757477.

63. Laštůvka, A.; Zdeněk, L.; Liška, J.; Šumpich, J. Motýli a Housenky Střední Evropy V., Drobní Motýli I; Academia, Praha: Prague, Czech Republic, 2018; ISBN 978-80-200-2852-5.

64. McKinney, M.L. Effects of urbanization on species richness: A review of plants and animals. Urban Ecosyst. 2008, 11, 161-176. [CrossRef]

65. Tack, A.; Ovaskainen, O.; Pulkkinen, P.; Roslin, T. Spatial location dominates over host plant genotype in structuring an herbivore community. Ecology 2010, 91, 2660-2672. [CrossRef]

66. Gripenberg, S.; Ovaskainen, O.; Elly, M.; Roslin, T. Spatial population structure of a specialist leaf-mining moth. J. Anim. Ecol. 2008, 77, 757-767. [CrossRef]

67. Bañuelos, M.J.; Kollmann, J. Effects of host-plant population size and plant sex on a specialist leaf-miner. Acta Oecol. 2011, 37, 58-64. [CrossRef]

68. Valdés-Correcher, E.; van Halder, I.; Barbaro, L.; Castagneyrol, B.; Hampe, A. Insect herbivory and avian insectivory in novel native oak forests: Divergent effects of stand size and connectivity. For. Ecol. Manag. 2019, 445, 146-153. [CrossRef]

69. Jactel, H.; Brockerhoff, E.G. Tree diversity reduces herbivory by forest insects. Ecol. Lett. 2007, 10, 835-848. [CrossRef] [PubMed]

70. Moreira, X.; Abdala-Roberts, L.; Rasmann, S.; Castagneyrol, B.; Mooney, K.A. Plant diversity effects on insect herbivores and their natural enemies: Current thinking, recent findings, and future directions. Curr. Opin. Insect Sci. 2016, 14, 1-7. [CrossRef] [PubMed]

71. Dai, X.; Long, C.; Xu, J.; Guo, Q.; Zhihong, Z.; Bater, Z. Are dominant plant species more susceptible to leaf-Mining insects? A case study at Saihanwula Nature Reserve, China. Ecol. Evol. 2018, 8, 7633-7648. [CrossRef] [PubMed]

72. O'Rourke, M.E.; Petersen, M.J. Extending the 'resource concentration hypothesis' to the landscape-scale by considering dispersal mortality and fitness costs. Agric. Ecosyst. Environ. 2017, 249, 1-3. [CrossRef]

73. Pincebourde, S.; Woods, H.A. Climate uncertainty on leaf surfaces: The biophysics of leaf microclimates and their consequences for leaf-dwelling organisms. Funct. Ecol. 2012, 26, 844-853. [CrossRef]

74. Sinclair, R.J.; Hughes, L. Leaf miners: The hidden herbivores. Austral Ecol. 2010, 35, 300-313. [CrossRef] 
75. Preszler, R.W.; Price, P.W. A Test of Plant-Vigor, Plant-Stress, and Plant-Genotype Effects on Leaf-Miner Oviposition and Performance. Oikos 1995, 74, 485-495. [CrossRef]

76. Bairstow, K.A.; Clarke, K.L.; McGeoch, M.A.; Andrew, N.R. Leaf miner and plant galler species richness on Acacia: Relative importance of plant traits and climate. Oecologia 2010, 163, 437-448. [CrossRef] [PubMed]

77. Krstić, M.R.; Kanjevac, B.R.; Babić, V.P. Effects of extremely high temperatures on some growth parameters of sessile oak (Quercus petraea/Matt./Liebl.) seedlings in northeastern Serbia. Arch. Biol. Sci. 2018, 70, 521-529. [CrossRef]

78. Faeth, S. Novel aspects of host tree resistance to leafminers. In Forest Insect Guilds: Patterns of Interaction with Host Trees; Baranchikov, Y.N., Mattson, W.J., Hain, F.P., Eds.; General Technical Report NE-153; Department of Agriculture, Forest Service, Northeastern Forest Experiment Station: Radnor, PA, USA, 1991; pp. 219-239.

79. Southwood, R.T.E.; Wint, W.G.R.; Kennedy, C.E.J.; Greenwood, S.R. Seasonality, abundance, species richness and specificity of the phytophagous guild of insects on oak (Quercus) canopies. Eur. J. Entomol. 2004, 101, 43-50. [CrossRef]

80. Muiruri, E.W.; Barantal, S.; Iason, G.R.; Salminen, J.P.; Perez-Fernandez, E.; Koricheva, J. Forest diversity effects on insect herbivores: Do leaf traits matter? New Phytol. 2019, 221, 2250-2260. [CrossRef]

81. Castagneyrol, B.; Giffard, B.; Péré, C.; Jactel, H. Plant apparency, an overlooked driver of associational resistance to insect herbivory. J. Ecol. 2013, 101, 418-429. [CrossRef]

82. Valdés-Correcher, E.; Bourdin, A.; González-Martínez, S.C.; Moreira, X.; Galmán, A.; Castagneyrol, B.; Hampe, A. Leaf chemical defences and insect herbivory in oak: Accounting for canopy position unravels marked genetic relatedness effects. Ann. Bot. 2020, 126, 865-872. [CrossRef]

83. Valencia-Cuevas, L.; Tovar-Sánchez, E. Oak Canopy arthropod communities: Which factors shape its structure? Rev. Chil. Hist. Nat. 2015, 88. [CrossRef]

84. Shimadzu, H.; Dornelas, M.; Henderson, P.A.; Magurran, A.E. Diversity is maintained by seasonal variation in species abundance. BMC Biol. 2013, 11,1-9. [CrossRef]

85. Lemieux, J.; Cusson, M. Effects of Habitat-Forming Species Richness, Evenness, Identity, and Abundance on Benthic Intertidal Community Establishment and Productivity. PLoS ONE 2014, 9, e109261. [CrossRef]

86. Bellamy, A.S.; Svensson, O.; van den Brink, P.J.; Gunnarsson, J.; Tedengren, M. Insect community composition and functional roles along a tropical agricultural production gradient. Environ. Sci. Pollut. Res. 2018, 25, 13426-13438. [CrossRef]

87. Tsafack, N.; Di Biase, L.; Xie, Y.; Wang, X.; Fattorini, S. Carabid community stability is enhanced by carabid diversity but reduced by aridity in Chinese steppes. Acta Oecol. 2019, 99, 103450. [CrossRef]

Publisher's Note: MDPI stays neutral with regard to jurisdictional claims in published maps and institutional affiliations.

(C) 2020 by the authors. Licensee MDPI, Basel, Switzerland. This article is an open access article distributed under the terms and conditions of the Creative Commons Attribution (CC BY) license (http://creativecommons.org/licenses/by/4.0/). 